PRZEGLĄD NAUK HISTORYCZNYCH 2019, R. XVIII, NR 1

http://dx.doi.org/10.18778/1644-857X.18.01.08

\title{
Instytut Historii Uniwersytetu Lódzkiego w realiach PRL. Wybrane zagadnienia
}

Streszczenie. Instytut Historyczny (IH) Uniwersytetu Łódzkiego został utworzony 24 czerwca 1948 r. Pierwsze lata jego działalności przypadły na okres stalinizmu. Kadra i studenci zostali wtedy poddani propagandzie i byli angażowani w różne akcje polityczne, a badaniom i dydaktyce narzucono metodologię marksistowsko-leninowską. Swój sprzeciw wobec tych praktyk studenci IH wyrazili w 1956 r. i dlatego w kolejnych latach nastapiło wiele korzystnych zmian. Jedna $z$ nich była możliwość wyjazdów pracowników do archiwów i bibliotek w krajach zachodnich. Niestety w 1968 r. Instytut doświadczył wielu politycznych wstrzasów. Następstwem uruchomionej wtedy kampanii antysemickiej było zwolnienie $z$ pracy i wyjazd $z$ Polski czterech pracowników IH. W kolejnych latach funkcjonowanie Instytutu i życie studentów ponownie poddano silnej presji politycznej. Jej wyrazem były np. obowiązkowe praktyki robotnicze dla studentów I roku. Dopiero gdy w 1980 r. powstał Niezależny Samorząny Związek Zawodowy „Solidarność” w Instytucie sytuacja się zmieniła. Studenci i pracownicy zaczęli walczyć o swoje interesy. Ci pierwsi uczestniczyli nawet w trwającym blisko miesiąc strajku okupacyjnym (styczeń-luty 1981 r.). Po wprowadzeniu stanu wojennego dwóch studentów zostało internowanych, poza tym pracownikom i studentom zabroniono prowadzenia wszelkiej niezależnej działalności. Niektórzy z nich podjęli jednak aktywność w podziemiu. Jawna działalność niezależna została na nowo podjęta dopiero w maju 1988 r. Powstał wtedy w IH samorzad studencki. Studenci i pracownicy włączyli się też w przemiany, które nastąpiły w 1989 r. Jeden z adiunktów został nawet posłem na Sejm (tzw. Sejm kontraktowy).

Słowa kluczowe: Uniwersytet Łódzki, Instytut Historii, historycy polscy, studenci w Polsce.

* Wydział Filozoficzno-Historyczny, Instytut Historii, Katedra Historii Polski i Świata po 1945 roku, e-mail: krzysztof.lesiakowski@uni.lodz.pl. 
S iedemdziesiąt lat istnienia Instytutu Historycznego, od $1970 \mathrm{r}$. Instytutu Historii (dalej: IH), Uniwersytetu Łódzkiego (dalej: UŁ) skłania do analizy jego dziejów. Warto chociażby spojrzeć na to zagadnienie przez pryzmat przemian, zwłaszcza politycznych, które się wtedy dokonywały w Polsce ${ }^{1}$. Jest oczywiste, że w Instytucie badano historię, ale i bieżące wydarzenia $-z$ dzisiejszej perspektywy: też już historia - oddziaływały na tę placówkę naukową, jego pracowników i studentów. Stąd pytanie o tę nieuniknioną wspó1zależność IH i świata zewnętrznego wydaje się mieć swoje uzasadnienie poznawcze. Poczynione ustalenia powinny dostarczyć materiału do refleksji ogólniejszych, choćby dotyczących porównań z sytuacją w podobnych ośrodkach naukowych.

\section{Instytut w dobie stalinizmu}

Instytut Historyczny w ramach UŁ został utworzony 24 czerwca 1948 r. Jednak już 13 września 1945 r. podczas II posiedzenia Komisji Głównej prof. Natalia Gąsiorowska (pierwszy przewodniczący/ kierownik Instytutu) przedstawiając dezyderaty wydziałowej Komisji Historycznej, nadmieniła o inicjatywie „utworzenia instytutu historycznego w zależności od możliwości lokalowych $z$ zachowaniem autonomii poszczególnych grup nauk historycznych, z zastrzeżeniem osobnych dotacyj dla każdej katedry zgrupowanej w instytucie" ${ }^{2}$. Koncepcja połączenia odrębnych katedr w instytut wynikała z zamiaru wzmocnienia pozycji środowiska historycznego i ułatwienia mu prowadzenia efektywniejszych badań oraz dydaktyki.

Nad pierwszym okresem dziejów IH mocno zaciążył stalinizm. Przebudowano w tym czasie programy i tok kształcenia, rosła rola zagadnień dotyczących doktryny marksistowsko-leninowskiej, polityka kadrowa znalazła sie pod kontrola czynnika partyjnego, pracowników i studentów angażowano do działań polityczno-propagandowych, a osobami traktowanymi jako niepewne, np. Helena

${ }^{1}$ Dzieje IH były już przedmiotem zainteresowania historyków. W badaniach tych koncentrowano się jednak na sprawach formalnych, stanie bazy materialnej, zbiorach biblioteki itp. Kontekst polityczny pomijano lub omawiano w sposób zdawkowy. Por. Osiagnięcia naukowe i dydaktyczne Instytutu Historii UŁ $w$ latach 1948-1988, „Acta Universitatis Lodziensis”, Folia Historica 31, 1988, s. 4-15; Uniwersytet Łódzki. Informator Instytutu Historii, Łódź 1998.

${ }^{2}$ Sprawozdanie $z$ II posiedzenia Komisji Głównej dla spraw Wydziału Humanistycznego UŁ, 13 IX 1945, Archiwum Uniwersytetu Łódzkiego [dalej: AUŁ], Wydział Humanistyczny, 3, karty bez paginacji. 
Brodowską, interesował się Urząd Bezpieczeństwa ${ }^{3}$. W instytucie mocna pozycję miały wtedy komórki Polskiej Zjednoczonej Partii Robotniczej (dalej: PZPR) i Związku Młodzieży Polskiej (dalej: ZMP). Pełniły one funkcję politycznego nadzorcy nad poczynaniami pracowników, a w przypadku młodszej kadry wręcz decydowały o ich karierze, np. popierajac lub nie ich wnioski o aspiranturę $e^{4}$ Prowadząc „walkę z pozostałościami liberalnymi”, często analizowano postawy profesorów i pozostałych pracowników. Warto tutaj przywołać informacje $z$ posiedzenia komórki partyjnej w IH z 22 stycznia 1950 r. O prof. Józefie Wolskim powiedziano wtedy, że: „Pod względem naukowym - umie dość dużo - nie ma jednak autorytetu naukowego. [...] Jest daleki od marksizmu". Profesorowi Józefowi Dudkiewiczowi zarzucono, że "pisze łatwo ale "obiektywistycznie". Natomiast w odniesieniu do prof. Stanisława F. Zajaczkowskiego padły słowa, że „wykazuje minimum dobrej woli” i „chce być jak najbardziej lojalnym". O dwóch jego asystentach: Władysławie Bortnowskim i Stefanie Krakowskim napisano, że „obaj są bojowi”, ale ten pierwszy miał gorsza przeszłość - był w sanacyjnym Legionie Młodych w Wilnie przed 1939 r. Krakowski zaś budził zastrzeżenia, bo od pół roku nie mógł się zdecydować na zadeklarowanie wstapienia do partii, gdyż pozostawał pod wpływem „reakcyjnej rodziny”.

W stalinowskich realiach także kształceniu studentów nadano właściwe tej epoce zabarwienie polityczne. Na grunt uniwersytecki zaczęto przenosić hasła ze świata produkcji, podobnie jak w fabrykach, dążono do zwiększonej wydajności. Dlatego do sesji egzaminacyjnej, pracownicy i studenci przygotowywali się jak do przedsięwzięcia produkcyjnego, a uzyskane wyniki analizowano podczas tzw. narad produkcyjnych. W tej z 14 listopada 1952 r. uczestniczyli studenci II roku historii. O wadze spotkania niech świadczy obecność przedstawiciela ministerstwa, a także

${ }^{3}$ Doniesienie agenturalne nr 1331, 6 XII 1953, Archiwum Instytutu Pamięci Narodowej w Warszawie - Biuro Udostepniania [dalej: AIPN BU], 00169/79/2, k. 68-69; Sprawozdanie naczelnika Wydziału V-go UBP na m[iasto] Łódź za m[iesia]c grudzień 1951 r., [1952], Archiwum Instytutu Pamięci Narodowej w Łodzi [dalej: AIPN Łd], Ld Pf 10/310, k. 7.

4 Wzorowana na doświadczeniach sowieckich aspirantura miała zastapić dotychczasowe, uważne za „burżuazyjne”, doktoraty. Por. R. Stobiecki, Historia pod nadzorem. Spory o nowy model historii w Polsce (II połowa lat czterdziestych - poczatek lat pięćdziesiątych), Łódź 1993, s. 100.

5 Protokół, 22 I 1950, Archiwum Państwowe w Łodzi [dalej: APŁ], Komitet Uczelniany Polskiej Zjednoczonej Partii Robotniczej [dalej: KU PZPR], 92, k. 26. 
delegata rektora, dziekana Wydziału Filozoficzno-Historycznego, prof. dr. Bohdana Baranowskiego, opiekuna roku, dr Zofii Libiszowskiej i szeregu wykładowców. W referacie wprowadzającym studentka Cieślak (imienia nie ustalono) odniosła się do właśnie realizowanego w Polsce planu sześcioletniego, akcentując, że młodzież studiująca ma też „na swoim odcinku poważne zadania”. Tymczasem - jej zdaniem - rysowały się zagrożenia w zakresie wykonania planu terminowego zakończenie studiów przez niektórych studentów, gdyż w minionej sesji było sporo ocen niedostatecznych, a $z$ trzech egzaminów najgorzej wypadł ten $z$ podstaw marksizmu-leninizmu, czyli z przedmiotu, który „powinien być przez nas szczególnie zrozumiany i opanowany"6.

Studentów historii nie zabrakło w realizowanych w dobie stalinizmu przedsięwzięciach polityczno-propagandowych. Na okoliczność hucznie obchodzonych urodzin prezydenta Bolesława Bieruta w kwietniu 1952 r. III rok historii zobowiazał się do „zorganizowania trzech referatów $z$ zakresu historii (na zakładach pracy ewentualnie w szkołach)", natomiast koło naukowe historyków zapowiedziało urządzenie wystawy pt. „10-lecie PPR” $z$ - jak zaznaczono - „specjalnym uwzględnieniem tow. Bieruta”. Dwuosobowe delegacje $z$ poszczególnych lat uczestniczyły w lipcu 1952 r. w Zlocie Młodych Przodowników Budowniczych Polski Ludowej ${ }^{7}$. Studenci historii brali też udział w propagandowo nagłośnionej dyskusji nad nowa konstytucja czy agitacji przedwyborczej, np. w związu $z$ wyborami do rad narodowych w grudniu 1954 r. jako agitatorów i prelegentów przydzielono 62 studentów historii ${ }^{8}$. Wyrazem uczestnictwa studentów w akcjach polityczno-propagandowych było również włączenie ich do składu ekip realizujących program tzw. łączności miasta ze wsią. Wiosna 1954 r. w pracy agitacyjnej oraz fizycznej w jednej ze spółdzielni produkcyjnych na terenie powiatu łódzkiego wyróżniała się ekipa II roku historii. To za jej

${ }^{6}$ Referat, 14 XI 1952, AUŁ, Dział Nauczania, 187, karty bez paginacji; Protokół z narady produkcyjnej drugiego roku historii UŁ, 16 XI 1952, ibidem, karty bez paginacji. Dziękuję Piotrowi Budzyńskiemu za udostępnienie kopii tego dokumentu.

7 Referat, [1952], AUŁ, Dział Nauczania, 187, karty bez paginacji; Zobowiazanie, [1952], Katedra Historii Polski i Świata po 1945 r. [dalej: KHPŚ] UŁ, Materiały nieopracowane [dalej: $\mathrm{MN}$ ], karty bez paginacji.

8 Sprawozdanie $z$ udziału pracowników i studentów UŁ w akcji wyborczej 17 Obwodowego Komitetu Frontu Narodowego, cz. 2, [1954], KHPS, MN, karty bez paginacji. 
sprawa chłopi ze wsi Rosanów mieli się wywiązać z obowiązkowych dostaw ${ }^{9}$. Ta i inne ekipy wzięły udział w organizacji obchodów 1 Maja w środowisku wiejskim. W klimacie tego politycznego entuzjazmu popełniono jednak polityczne błędy. W sprawozdaniu napisano, że: „Ekipa historyków chciała w niewłaściwy, mechaniczny sposób zwiększyć szeregi organizacji partyjnej na wsi"10. Studenci jeździli też do Państwowych Gospodarstw Rolnych, udzielając im pomocy w żniwach i podczas wykopków ziemniaków.

\section{Odwilż i przemiany $1956 \mathrm{r}$.}

Jest oczywiste, że dynamiczne zmiany dokonujące się w Polsce po śmierci Józefa Stalina, zwłaszcza w 1956 r. nie mogły ominąc IH. Najistotniejsza było przeniesienie się $z$ dotychczasowej siedziby przy ul. Lindleya 3 do budynku przy ul. Buczka 27, w którym przed 1939 r. mieściła się Fabryka Wyrobów Jedwabniczych K. Reisfeld SA. Po wojnie znalazł się on w dyspozycji Urzędu Bezpieczeństwa Publicznego (dalej: UBP). Niestety nie udało sie jednoznacznie stwierdzić, jaka komórka się tutaj zainstalowała. Według oficjalnego instytutowego dokumentu z 1974 r. był to "wydział więziennictwa i klub pracowników tego wydziału". Natomiast z ustaleń Instytutu Pamięci Narodowej wynika, że w tym obiekcie miał swoja siedzibę Wydział Śledczy UBP na miasto Łódź ${ }^{11}$. W lipcu 1954 r. urząd ten zlikwidowano, włączając go w struktury urzędu wojewódzkiego ${ }^{12}$. Przy okazji, ze względu na rysujące się tendencje odwilżowe, w jednej i drugiej instytucji zmniejszano zatrudnienie. W efekcie aparat bezpieczeństwa pozbywał się też zbędnych budynków. Jednym $z$ nich był ten na ul. Buczka ${ }^{13}$.

9 A. Ciota, Działalność ZMP na Uniwersytecie Eódzkim w latach 1948-1956, Łódź 1982, k. 69-70 [praca magisterska przechowywana w IH UŁ].

10 Protokół z zebrania Podstawowej Organizacji Partyjnej PZPR, 5 VI 1954, KHPS, MN, karty bez paginacji. Por. też Protokół z posiedzenia Egzekutywy POP, 10 III 1954, ibidem, karty bez paginacji.

${ }_{11}$ Materiały na konferencje Zespołu Partyjnego Komitetu Nauk Historycznych PAN w Instytucie Historii UŁ, Łódź 1974, s. 6; Struktury i kadra kierownicza urzędów bezpieczeństwa publicznego w województwie łódzkim w latach 1945-1956, red. R. Rabiega i J. Żelazko, Łódź 2019, s. 53 [w druku].

12 Struktury i kadra kierownicza..., s. 58, 63.

13 Po 1956 r. władze Łodzi przejęły też więzienie przy ul. Gdańskiej 13, aby w 1959 r. podjąć decyzję o utworzeniu w tym miejscu Muzeum Ruchu Rewolucyjnego. Por. K. Les iakows ki, Więzienie śledcze przy ul. Gdańskiej 13, [w:] Budownictwo wojskowe w Łodzi, red. W. Jarno, P. Waingertner, Łódź 2016, s. 217-218. 
Przeprowadzkę zorganizowano w dniach 10-13 grudnia 1954 r. ${ }^{14}$ Obok IH w obiekcie znalazły się też inne komórki uniwersyteckie. Jako ciekawostkę można podać, że jedna $z$ nich był Studencki Teatr Satyryczny „Pstrą" (powstał w grudniu 1954 r.), który zajał pomieszczenia klubowe dawnej bezpieki na III piętrze. Interesujące, że uniwersytecka organizacja partyjna, a dokładniej Stefan Banasiak, widząc działania zespołu, w tym nocne próby, co siła rzeczy przekładało się na nieobecności studentów-aktorów w czasie zajęć w kolejnym dniu, wyrażała swoje zaniepokojenie $z$ tego powodu ${ }^{15}$.

Dało się także zauważyć inne zjawiska odwilżowe. Najpoważniejszym była rosnąca fala dyskusji, a nawet sporów, także między pracownikami, w kontekście bilansowania dotychczasowych dokonań. Zaczęto chociażby dostrzegać konieczność zmiany zarządzeń dotyczących obowiązującej dyscypliny studiów. Zauważono również, że młodzież studencka w IH niespecjalnie chciała zajmować się zagadnieniami politycznymi, sygnalizowała własne problemy - krytykowała niektórych wykładowców i domagała się "godziwej rozrywki"16. W ogniu krytyki znalazła się też uniwersytecka Komisja Przydziału Pracy, nazywana „piekielną machina”. Rzecz jasna, że nawet w kręgu ZMP i PZPR Instytutu nie mogła przejść niezauważona publikacja słynnego „Poematu dla dorosłych” przez „Nowa Kulturę" w sierpniu 1955 r. Podczas zebrania Oddziałowej Organizacji Partyjnej Józef Śmiałowski (od listopada I sekretarz tej komórki) wyraził opinię, że niewątpliwie dyskusja o „Poemacie dla starszych" [sic!] jeszcze się nasili i w związku z tym należy się „przeciwstawić niezdrowym poglądom”, pokazując pozytywne osiągnięcia Polski Ludowej ${ }^{17}$.

Rok 1956 w całej Polsce był okresem wielkiego pobudzenia, także świata akademickiego. Aktywni byli również studenci historii na UŁ. Najpierw doszło do incydentu $z$ egzaminem $z$ marksizmu-leninizmu (trudno ustalić, czy była to sesja letnia czy zimowa). Gdy

${ }^{14}$ Do Zastępcy Rektora do spraw Administracyjnych UŁ, [1954], KHPS, MN, karty bez paginacji.

15 Protokół z posiedzenia Egzekutywy P[odstawowej] O[rganizacji] P[artyjnej] przy UŁ, 14 XII 1955, KHPS, MN, karty bez paginacji.

${ }_{16}$ Protokół z posiedzenia Egzekutywy POP przy UŁ, 13 X 1956, KHPS, MN, karty bez paginacji.

17 Protokół nr 3 z zebrania egzekutywy O[ddzialowej] O[rganizacji] P[artyjnej] Wydziału Filozoficzno-Historycznego, 22 XI 1955, KHPS, MN, karty bez paginacji. 
doc. Henryk Katz wyrzucił pięciu studentów z gabinetu, pozostali odmówili przystąpienia do egzaminu ${ }^{18}$. Taki incydent mógł zajść tylko w realiach wyzwalania się środowiska studenckiego ze stalinowskich dogmatów i dyscypliny studiów. Fakt, że władze uczelni zmieniły egzaminatora, oznaczał, że duch zmian wyraźnie postępował. Poważne przyśpieszenie tego procesu nastąpiło jesienią. Wielkim wydarzeniem utrzymanym $\mathrm{w}$ klimacie radości $z$ odzyskiwanej przez Polaków podmiotowości we własnym kraju był potężny wiec w hali „Wimy” na Widzewie 23 października. Sądzić należy, że uczestniczyli $\mathrm{w}$ nim studenci historii. O ich aktywnej postawie świadczy bowiem własny wiec, który zorganizowali w auli IH. Tutaj $\mathrm{ku}$ ich zaskoczeniu wspomniany doc. H. Katz wystapił jako zwolennik październikowych przemian, zachęcając zgromadzonych do wytrwania w walce o liberalizację życia w Polsce. Jednak, jak stwierdził uczestnik tego zgromadzenia, jego słowa, że tzw. materia, czyli sowieckie czołgi, których interwencji się obawiano (przykład Węgier), nie pokona ducha, nie trafily na podatny grunt. Podobno zostały one wręcz uznane za prowokację ${ }^{19}$.

O IH znów było głośno na początku następnego roku. W dniu 17 stycznia 1957 r. w instytutowej auli zorganizowano zebranie w związku $z$ trwająca kampania przed wyborami do Sejmu, zaplanowanymi na 20 stycznia. W IH pojawili się główni kandydaci na posłów: Roman Zambrowski, Ignacy Loga-Sowiński, a także Michalina Tatarkówna-Majkowska - I sekretarz Komitetu Łódzkiego (dalej: KŁ) PZPR ${ }^{20}$. Spotkanie to miało przyczynić się do wzmocnienia pozycji wspomnianej działaczki w środowisku akademickim, z którym była w ostrym konflikcie od momentu skreślenia $z$ listy kandydatów na posłów osoby, która popierali łódzcy studenci.

\section{W latach siermiężnego socjalizmu}

Po 1956 r. w Instytucie stopniowo następowały korzystne zmiany organizacyjne, za którymi poszedł wzrost liczby zatrudnionych. $\mathrm{Na}$ początku 1965 r. w jego ramach funkcjonowało siedem katedr i 13 zakładów, w których pracowało 14 pracowników samodziel-

18 P. Budzyński, Studenckie Koło Naukowe Historyków Uniwersytetu Eódzkiego 1945-2016, Łódź 2017, k. 31 [praca licencjacka przechowywana w IH UŁ].

19 Ibidem, k. 31.

20 P. Ossowski, Czerwona Michalina. Michalina Tatarkówna-Majkowska. Prządka-działaczka- łodzianka, Łódź 2017, s. 135. 
nych, 22 pomocniczych, trzech technicznych i trzech administracyjnych. Gomułkowskie poluzowanie wpłynęło także na zwiększenie się zasobu biblioteki IH. Potrzebne publikacje pozyskiwano, m.in. nawiazując kontakty $z$ podmiotami zagranicznym, np. The New York Public Library, ale też z Biblioteką Polską w Paryżu, Polskim Towarzystwem Historycznym na Obczyźnie ${ }^{21}$. Podjęto także działania na rzecz zbudowania zaplecza technicznego dla dydaktyki i badań naukowych. Jako ciekawostkę można podać informację, że gdy w 1957 r. przymierzano się do zakupu pierwszego episkopu, to pojawił się pomysł, aby o środki na ten cel wystapić do Fundacji Rockefellera ${ }^{22}$.

Istotna zmianą było to, że pracownicy naukowi zyskali możliwość wyjazdów na badania w krajach zachodnich. Odpowiednie służby państwowe ciagle jednak kontrolowały i limitowały kontakty ze światem. Przykładowo: gdy Służba Bezpieczeństwa (dalej: SB) ustaliła, że dr Zofia Libiszowska nawiązała kontakt korespondencyjny $z$ emigracyjnym politykiem, prof. Stanisławem Kotem, to w lutym 1959 r. stała się celem obserwacji, która w 1960 r. została zaniechana $z$ uwagi na to, że nie potwierdzono jej dalszych kontaktów $z$ ta osoba $^{23}$. W przypadku magistra, a w przyszłości prof. Waldemara Michowicza naukowo uzasadniona potrzeba wyjazdów za granicę spowodowała, że pracownik ten został wmanewrowany w trzyletnia współpracę z SB jako informator o kryptonimie „Przyjaciel”24.

Nie był to jedyny przypadek skutecznego werbunku spośród pracowników. Od 1963 do 1968 r. był jeszcze informator o kryptonimie „Rene”. Z uwagi na brak materiałów - zachowały się jedynie za-

${ }^{21}$ Pismo od Publicznej Biblioteki w Nowym Jorku w sprawie wymiany wydawnictw, 19 I 1962, KHPS, MN, karty bez paginacji. Biblioteka Polska w Paryżu w lipcu 1957 r. podziękowała IH za przesłanie trzech książek, w tym B. Baranowskiego pt. Stosunki polski-tatarskie w latach 1632-1648, a od Polskiego Towarzystwa Historycznego na Obczyźnie w kwietniu 1958 r. otrzymano prace Tytusa Ko marnickiego pt. The Rebirth of the Polish Republic.

22 Do Dziekanatu Fil[ozoficzno]-History[cznego] UŁ, 6 VII 1957, KHPS, MN, karty bez paginacji; Do Referatu Zaopatrzenia UŁ, 19 II 1958, ibidem, karty bez paginacji; Do Dyrektora Instytutu Historycznego UŁ doc. dr. Tadeusza Błaszczyka, 20 I 1968, ibidem, karty bez paginacji.

${ }^{23}$ Sprawozdanie Wydziału III W[ojewódzkiej] K[omendy] MO w Łodzi za I kwartał 1960 r., kwiecień 1960, AIPN Łd, Pf 10/52, k. 24. Por. też Ocena sytuacji politycznej po środowiskach sanacyjnych i endecko-chadeckich za I kwartał 1959 r., 30 V 1959, ibidem, Pf 10/51, k. 60.

${ }^{24}$ J. Wróbel, Jerzy Kosiński a tajne służby, „Aparat Represji w Polsce Ludowej 1944-1989" 2007, nr 1, s. 214-218. 
pisy w dzienniku rejestracyjnym Komendy Wojewódzkiej Milicji Obywatelskiej (dalej: MO) - nie można określić zakresu tej współpracy ${ }^{25}$.

W omawianym okresie zelżała jednak presja polityczna na pracowników, ale $z$ całą pewnością ona nie zniknęła. Ciagle przecież funkcjonowała komórka PZPR, niektórzy zatrudnieni współpracowali z Wieczorowym Uniwersytetem Marksizmu-Leninizmu czy Referatem Historii Partii przy KŁ PZPR. Byli oni także angażowani w różne kampanie polityczne tego okresu, np. odczyty w ramach obchodów Tysiąclecia Państwa Polskiego. Jednocześnie była analizowana ich postawa i wszelkie komentarze na temat panujaccego ustroju. Znamienne i ważne w kontekście późniejszych wydarzeń jest to, że na początku 1965 r. SB sformułowała opinię, że na Wydziale Filozoficzno-Historycznym zawiązał się krag towarzyski, w którym rzekomo propagowano teorie negujące kierowniczą rolę partii i słuszność prowadzonej polityki gospodarczej. Do tego kręgu spośród historyków zaliczono Jakuba Goldberga, Adama Leśniewskiego, Pawła Korca, Leona Tadeusza Błaszczyka, Henryka Katza, a poza tym Stefana Amsterdamskiego i Jolantę Kulpińską ${ }^{26}$. W nieodległej przyszłości, tzn. w Marcu 1968 r., właśnie przeciwko tym osobom zostanie podjety atak polityczny i propagandowy.

W kontekście zainteresowania SB sytuacją w środowisku historyków w okresie przed wybuchem kryzysu marcowego można jeszcze dodać, że w jednym $z$ materiałów informacyjnych $z$ maja 1967 r. pisano, że w IH „jest jeszcze pewna grupa naukowców, która wywodzi się z tzw. "lepszych sfer", a która do dnia dzisiejszego nie może w sobie wskrzesić elementów zainteresowania zagadnieniami współczesności, szczególnie dot[yczącymi] historii współczesnej Polski, takimi jak problem działalności partii robotniczych i budownictwo socjalizmu./ Grupa tych naukowców uważa, że wartościowe prace naukowe można jedynie pisać na tematy związane $z$ dawnymi dziejami. Jeżeli się zdarzaja wyjątki tematyczne to sa pisane w sposób nie oddający wiernie faktów, np. dr [Tadeusz] Telma opracował pracę doktorska nt. "Walka $z$ reakcyjnym podziemiem na terenie woj. łódzkiego w latach 1945-1947 «27 - w której

${ }^{25}$ Dziennik rejestracyjny W[ojewódzkiej] K[omendy] MO w Łodzi, nr 2071, AIPN Łd, 0255/1, karty bez paginacji; Dziennik archiwalny. Sygnatury I K[omendy] M[iejskiej] MO w Łodzi, nr 38913, ibidem, 0313/12, karty bez paginacji.

${ }^{26}$ Informacja dot[ycząca] sytuacji wśród pracowników wyższych uczelni, 15 II 1965, AIPN Łd, Pf 10/525, k. 37-40.

${ }^{27}$ Dokładny tytuł tej rozprawy to: $Z$ dziejów walk $z$ podziemiem $w$ województwie łódzkim 1945-1947. 
dość jaskrawo gloryfikował osobę Warszyca ${ }^{28}$ i jego działalność"29. Nie ulega wątpliwości, że informacja ta nie oddawała rzeczywistego obrazu zagadnień badanych przez pracowników IH.

Jeśli chodzi o studentów, to należy powiedzieć, że tak jak inne środowiska, po opadnięciu fali emocji $z$ jesieni 1956 r. zostali oni wtłoczeni w ramy przeznaczonych dla nich organizacji. Były to Związek Młodzieży Socjalistycznej (dalej: ZMS), Związek Młodzieży Wiejskiej (dalej: ZMW) oraz Zrzeszenie Studentów Polskich (dalej: ZSP). O tych organizacjach na terenie IH trudno jednak się konkretnie wypowiedzieć. Dysponujemy jedynie danymi $z$ poziomu uczelnianego. Według stanu z 1960 r. na Uniwersytecie działały: ZSP - 1026 członków, ZMS - 141 członków, ZMW - 80 członków oraz Akademicki Zwiąek Sportowy - 225 członków. Opiekunem ZMS był dr Stefan Banasiak (według stanu $z$ końca lat sześćdziesiątych) ${ }^{30}$. Większa wiedzę mamy za to o studenckim kole naukowym historyków. W 1960 r. miało ono 41 członków i było trzecim co do wielkości na UŁ, po kole młodych prawników - 67 i geografów - 54 członków. W tym momencie na jego czele stał Marian Wilk, a opiekunem była doc. dr H. Brodowska ${ }^{31}$.

Charakteryzujac studentów, należy jednak odnotować, że w roku 1958 trzem studentom historii, w tym przyszłemu prof. Waldemarowi Ceranowi, zarzucono „prowadzenie nielegalnej organizacji na terenie Uniwersytetu" i w zwiąku $z$ tym wnioskowano o ocenę ich postawy przez Komisję dyscyplinarną UŁ ${ }^{32}$. Okoliczności sprawy, jak i jej ewentualny dalszy bieg nie sa jednak znane. Istnieje opinia, że w rzeczywistości chodziło jedynie o reaktywowanie koła naukowego historyków, co miało nastapić bez uprzedniej zgody wład $z^{33}$.

${ }^{28}$ Chodzi o Stanisława Sojczyńskiego ps. „Warszyc”, który w 1945 r. zorganizował i do czerwca 1946 r. dowodził Konspiracyjnym Wojskiem Polskim, największa formacja powojennego podziemia niepodległościowego w Polsce centralnej.

${ }^{29}$ Informacja dot[yczacca] aktualnej sytuacji w wyższych uczelniach na terenie m. Łodzi, 22 V 1967, AIPN Łd, 10/836, k. 4.

${ }^{30}$ Pismo doc. dr. Stefana Banasiaka do Rektora UŁ, [1969], KHPS, MN, karty bez paginacji.

31 Do Ministerstwa Szkolnictwa Wyższego, 9 XI 1960, AUŁ, Dział Nauki, 231, karty bez paginacji; Zestawienie organizacji i kół naukowych według stanu w dniu 31 XII 1960, 15 III 1961, ibidem, karty bez paginacji.

${ }^{32}$ Do Rektora UŁ przez dziekanat [Wydziału] Filoz[oficzno]-Histor[ycznego], 29 IX 1958, KHPS, MN, karty bez paginacji; https://ceraneum.uni.lodz.pl/o-patronie/biogram-2 (dostęp: 30 XI 2018).

${ }^{33}$ P. Budzyński, op. cit., k. 31. 
Dużym wstrząsem dla Polski, a szczególnie środowiska akademickiego i inteligenckiego, stała się rewolta $z$ marca 1968 r. Łódź wprawdzie nie była wiodącym ośrodkiem, jeśli chodzi o studenckie demonstracje, ale to tu odbyły się trzy wiece - 11, 12 i 19 marca. Głównym teatrem była Biblioteka UŁ i jej sassiedztwo. W tych wydarzeniach nie zabrakło studentów historii. Warto zauważyć, że na listach „aktywnych prowodyrów zajść na łódzkich uczelniach” - choć tego nie udało się potwierdzić - znaleźli się chociażby Wiesław Caban (III rok), Antoni Galiński (IV rok) i Henryk Siemiński (I rok), ówcześni studenci historii ${ }^{34}$. W nocy z 21 na 22 marca w budynku IH odbył się też strajk okupacyjny, w którym brało udział 150 osób. W opałach znalazła się też doc. Z. Libiszowska, matka studentki socjologii zaangażowanej $\mathrm{w}$ trwającą rewoltę. $Z$ pewnościa powody do zaniepokojenia miała też doc. Krystyna Śreniowska $z$ uwagi na aktywność syna, który współorganizował strajk na Wydziale Ekonomiczno-Socjologicznym. Następstwem tego za kilka lat będzie blokada nadania jej tytułu profesorskiego.

Skutki Marca na gruncie instytutowym były bardzo poważne, relatywnie większe niż w wielu innych instytutach historycznych. Watki te były już opisywane przez historyków ${ }^{35}$. Do publikowanych informacji można dodać, że 6 kwietnia zwołano zebranie pracowników w sali nr 13. W jego trakcie przewidywano „dyskusję nad problematyka pracy ideowo-wychowawczej w środowisku akademickim w świetle ostatnich wydarzeń"36. Decyzje kadrowe zapadały jednak na forum partyjnym. Podstawowa Organizacja Partyjna PZPR przy Wydziale Filozoficzno-Historycznym 27 kwietnia 1968 r. zdecydowała o usunięciu $z$ partii doc. dr. P. Korca - kierownika Zakładu Historii Polski XX w. oraz doc. dr. L.T. Błaszczyka - dyrektora Instytutu Historycznego UŁ. W konsekwencji obaj zostali zwolnieni. Z pewnym opóźnieniem, bo w połowie 1969 r. z IH zwolniono

${ }^{34}$ Lista osób aktywnych prowodyrów zajść na łódzkich uczelniach, 1968, AIPN Łd, Pf 10/807, k. 10.

35 J. Eisler, Polski rok 1968, Warszawa 2006; K. Lesiakowski, Łódź, [w:] Oblicza Marca 1968, red. K. Rokicki, S. Stępień, Warszawa 2004; L. Olejnik, Żydzi łódzcy w latach 1956-1972, [w:] Społeczność żydowska w PRL przed kampania antysemicka lat 1967-1968 i po niej, red. G. Berendt, Warszawa 2009; W. Puś, Zarys historii Uniwersytetu Łódzkiego 1945-2015, Łódź 2015; K. Śr eniows ka, Moje życie, red. R. Stobiecki, J. Kolbuszewska, Łódź 2018; Marzec '68 $w$ Łodzi, red. S.M. Nowinowski, Łódź 2010.

${ }^{36}$ Informacja o zebraniu w Instytucie Historycznym UŁ, 6 IV 1968, KHPS, MN, karty bez paginacji. 
też byłego żołnierza armii brytyjskiej z lat 1943-1947, a w okresie schyłkowego stalinizmu kierownika Katedry Podstaw Marksizmu-Leninizmu - prof. H. Katza, wtedy kierownika Katedry Historii Powszechnej Nowożytnej ${ }^{37}$ i byłego więźnia Litzmannstadt Ghetto i obozu Auschwitz - dr. A. Leśniewskiego, pracownika tejże katedry (obu formalnie na własna prośbę) ${ }^{38}$. Wymienieni opuszczą Polskę na fali pomarcowej emigracji, najpóźniej zdecydował się na ten krok prof. H. Katz - w 1972 r., ale wcześniej przeniósł się do Warszawy $^{39}$. W efekcie nazwiska tych osób na gruncie instytutowym na długie lata odejdą w zapomnienie ${ }^{40}$.

Po takich wstrząsach sytuacja w IH i w ogóle na uniwersytecie pod wieloma względami musiała być bardzo skomplikowana. Według oceny prof. K. Śreniowskiej po 1968 r. uniwersytet stał się „domena dyktatu partii, uczelnia nomenklaturowa”"1.

\section{W dekadzie Gierka}

W nowa dekadę IH wchodził osłabiony i z obawami o swoja przyszłość. Na ten stan oddziaływały czynniki wewnętrzne i zewnętrzne. $Z$ uwarunkowań wewnętrznych należy wymienić wspomniane straty kadrowe. Dostrzegano to nawet w oficjalnych dokumentach, wytworzonych przez kierownictwo $\mathrm{UZ}^{42}$. Gdy do osób, które wyjechały po Marcu 1968 r., doda się tych, którzy odeszli na emerytury, zostali zwolnieni $z$ uwagi na słabe postępy w przygotowywaniu pracy doktorskiej czy przenieśli się do innych ośrodków, to okazuje się, że w ciagu sześciu lat 1967-1973 z Instytutu odeszło aż

37 Obywatel prof. dr Henryk Katz, 23 VII 1969, AUŁ, Akta osobowe, 4186, k. 192; Do Obywatela Rektora Uniwersytetu Łódzkiego, 30 VI 1969, ibidem, k. 190; Ankieta personalna, 30 VI 1953, ibidem, k. 16; Oddział Kadr UŁ, 7 XII 1956, ibidem, k. 119.

38 Do Pana Rektora Uniwersytetu Łódzkiego, 17 VI 1969, AUŁ, Akta osobowe, 4203, karty bez paginacji; Życiorys, b.d., ibidem, karty bez paginacji; Meldunek specjalny, 28 IV 1968, AIPN Łd, Pf 10/737, k. 12.

${ }^{39} \mathrm{Na}$ opuszczenie Łodzi miało wpłynąć zablokowanie wydania jego podręcznika dla szkół średnich, bo „polskie dzieci nie będą się uczyć z ksiażki napisanej przez Żyda”. Por. S. Bąkowicz, Mój uniwersytet. Wspomnienia byłego studenta, Łódź 2008, s. 71.

${ }^{40} \mathrm{Na}$ milczenie łódzkiego środowiska historycznego np. o osobie prof. H. Katza zwrócili uwage Jarosław Kita i Rafał S to biecki, autorzy Słownika biograficznego historyków łódzkich, Łódź 2000, s. 8-9.

${ }^{41}$ K. Śreniowska, op. cit., s. 216.

${ }^{42}$ Materiały na konferencje zespołu partyjnego..., s. 9. 
11 pracowników - tzn. około jedna trzecia kadry ${ }^{43}$. Okoliczność ta musiała rzutować na działalność naukową i dydaktyczną w dekadzie lat siedemdziesiatych.

Z czynników zewnętrznych najważniejsze były następstwa zmienionej w grudniu 1968 r. ustawy o szkolnictwie wyższym, która znosiła resztki akademickiej samorządności. Skutkiem ustawy była reorganizacja Instytutu w 1970 r. Inna sprawa, że dyskusję na ten temat w IH podjęto już w czerwcu 1968 r., gdy podczas posiedzenia Komisji Historycznej przedstawiono plany przekształceń ${ }^{44}$. Najogólniej mówiąc, reorganizacja sprowadzała się do likwidacji tradycyjnych katedr, które zostały zastapione zakładami. Kompetencje zakładów obejmować miały jedynie sprawy dydaktyczne, gdyż badania planowano skoncentrować w zespołach, koordynowanych przez dyrektora. Te okoliczności budziły liczne zastrzeżenia wśród pracowników, gdyż czasem oznaczało to zerwanie wcześniej istniejących więzi czy problemy $z$ zapewnieniem opieki nad niektórymi asystentami. Trzeba też pamiętać, że początkowo władze ministerialne wyraziły zgodę na utworzenie w łódzkim IH tylko pięciu zakładów. W praktyce ich liczba wzrosła jednak do siedmiu i jednej pracowni ${ }^{45}$.

Istotnym elementem nowego ładu znów stała się organizacja partyjna. Upartyjnienie kadry IH było duże. W 1974 r. na 44 pracowników do PZPR należało 24 i jeden do Zjednoczonego Stronnictwa Ludowego. Najsilniej upartyjniona była grupa asystentów i starszych asystentów (odpowiednio 75\% i 92\%) oraz docentów (50\%), gdy w grupie adiunktów było to 33\%, a spośród sześciu profesorów żaden nie deklarował przynależności partyjnej. Warto jednak zauważyć, że w wykorzystanym źródle w odniesieniu do tej ostatniej grupy dodano uwagę, która łagodziła wymowę istniejącej sytuacji: „Należy tutaj podkreślić, iż w naszym środowisku brak przynależności partyjnej nie może być utożsamiany $z$ brakiem zaangażowania politycznego" 46 .

${ }^{43}$ S. Ban a siak, Z dziejów Instytutu Historii, [w:] Uniwersytet Łódzki. Informator Instytutu Historii, Łódź 1998, s. 15.

${ }^{44}$ Protokół z rozszerzonego posiedzenia Komisji Historycznej IH UŁ, 4 VI 1968, AUŁ, Wydział Filozoficzno-Historyczny [dalej: WF-H], 669, k. 83-89.

${ }^{45}$ S. Banasiak, $Z$ dziejów Instytutu Historii..., s. 13-14; ide m, Ewolucja struktur organizacyjnych, rozwój kadry oraz bazy materialnej instytutu, „Acta Universitatis Lodziensis", Folia Historica 31, 1988, s. 8-10.

${ }^{46}$ Materiały na konferencje zespołu partyjnego..., s. 4, 13. 
Znając realia epoki, należy przyjąć, że IH musiał też być przedmiotem zainteresowania aparatu bezpieczeństwa. Według stanu z 10 kwietnia 1969 r., zatem w klimacie pomarcowego poruszenia, na Wydziale Filozoficzno-Historycznym SB miała tylko trzy osobowe źródła informacji (dwóch tajnych współpracowników i jeden kontakt operacyjny $)^{47}$. A przecież $\mathrm{w}$ tym czasie na wszystkich kierunkach wydziału studiowało ponad 500 studentów i było zatrudnionych 90 pracowników. W związku $\mathrm{z}$ tym należało się spodziewać, że zostana zintensyfikowane działania na rzecz poszerzenia listy informatorów. Faktycznie tak się stało. Już w 1971 r. SB zwerbowała $z$ grona kadry IH tw kryptonim "Nike” (wyrejestrowany w 1978 r.), a w 1978 r. tzw. konsultanta kryptonim „Dembowski” (wyrejestrowany w 1987 r. $)^{48}$.

Po doświadczeniach z młodzieżą akademicka w Marcu 1968 r. poszczególne uczelnie zobowiązano do wdrożenia w życie nowych programów pracy dydaktyczno-wychowawczej. Ich istotnym elementem były wprowadzone w 1970 r. praktyki robotnicze dla studentów I roku. Zostały one uznane za ważną część urzeczywistnienia „wychowania obywatelskiego młodzieży studenckiej"49. Natomiast głównym pomocnikiem władz uczelni w zakresie kształtowania oblicza młodzieży miał być powołany w 1973 r. Socjalistyczny Związek Studentów Polskich (dalej: SZSP). Jego przedstawiciel został upoważniony do uczestniczenia w posiedzeniach dyrekcji Instytutu.

47 Wykaz tajnych współpracowników zatrudnionych w niżej wymienionych instytucjach w/g stanu na dzień 30 III [19]69 r., 10 IV 1969, AIPN Łd, Pf 10/706/1, k. 444. Szerzej o różnych kategoriach osobowych źródeł informacji SB por. F. Mus iał, Podręcznik bezpieki. Teoria pracy operacyjnej Służby Bezpieczeństwa w świetle wydawnictw resortowych Ministerstwa Spraw Wewnętrznych PRL (1970-1989), Kraków 2007, s. 333-334, 348.

48 Kartoteka zniszczeniowa, AIPN Łd, Ld 0081/10, karty bez paginacji; Dziennik archiwalny teczek personalnych i wyeliminowanej agentury $\mathrm{nr} 42187$, ibidem, 0255/6, karty bez paginacji. Według dostępnych danych ewidencyjnych „Dębowski/Dembowski” od 1951 r. był współpracownikiem wojskowego, a od 1953 r. cywilnego aparatu bezpieczeństwa. W 1958 r. współpracę rozwiązano z powodu odmowy. Por. Kartoteka ogólnoinformacyjna, AIPN Łd, Ld 0081/1, karty bez paginacji; Kartoteka zniszczeniowa, ibidem, karty bez paginacji; Kartoteka odtworzeniowa, ibidem, Ld 00324/1, karty bez paginacji; Dziennik rejestracyjny [Wojewódzkiego Urzędu Spraw Wewnętrznych w Łodzi], ibidem, Ld 02255/4, karty bez paginacji.

49 Program działalności dydaktyczno-wychowawczej Uniwersytetu Łódzkiego, 7 V 1973, KHPS, MN, s. 8. 
Na gruncie IH trudno jednak uchwycić działalność SZSP. Wiadomo jedynie, że według stanu z 1973 r. w jego szeregach było 177 studentów, co stanowiło aż $75 \%$ ogółu studiujących historię. Byli oni podzieleni na osiem tzw. grup działania. Całościa kierowała Rada Oddziałowa tej organizacji (skupiała ona oprócz studentów historii, także tych $z$ etnografii, archeologii i filozofii). Znane sa tylko dwie inicjatywy tej organizacji $z$ terenu Instytutu - chęć zagospodarowania sali nr 48 na „czytelnię czasopism i miejsce rekreacji oraz wypoczynku dla studentów”. Druga to propozycja uruchomienia sprzedaży herbaty (studenci nie mogli w tym czasie korzystać $z$ istniejącej stołówki pracowniczej) $)^{50}$.

Natomiast $z$ cała pewnością $w$ dekadzie lat siedemdziesiątych $z$ dużym rozmachem rozwijał się studencki ruch naukowy. Funkcjonował on formalnie pod auspicjami SZSP. Koło naukowe organizowało sesje naukowe np. $z$ okazji 200 rocznicy powstania Komisji Edukacji Narodowej, ważnym dokonaniem były też obozy naukowe. W 1973 r. w kole było 48 studentów ${ }^{51}$. Później liczba ta znacząco zmalała, ale zmniejszenie się liczebności koła było przejściowym zjawiskiem.

\section{Solidarnościowe wrzenie i narastający marazm (1980-1989)}

Uruchomiona strajkami z sierpnia 1980 r. i powstaniem Niezależnego Samorządnego Zwiąku Zawodowego „Solidarność” lawina zmian ogarnęła także środowisko IH. O swoich problemach zaczęli wtedy głośno mówić pracownicy i studenci. Uaktywniły się też władze wydziału. Odbywajacca się w październiku Rada Wydziału Filozoficzno-Historycznego przyjęła uchwałę, że Senat UŁ powinien w najbliższym czasie wystapić $z$ deklaracją, która określałaby stosunek Uniwersytetu do zachodzacych w kraju przemian. Jeśli chodzi o pracowników IH, to 13 i 22 listopada odbyły się ich zebrania, które kończyły się przyjęciem dokumentów (uchwał) odnoszacych się do wydarzeń w Polsce i zawierających różne postulaty środowiska historycznego ${ }^{52}$.

\footnotetext{
${ }^{50}$ Pismo do Dyrekcji IH UŁ, 11 XI 1976, KHPS, MN, karty bez paginacji.

${ }^{51}$ Materiały na konferencje zespołu partyjnego..., s. 30. Por. też P. Budzyńs ki, op. cit., k. 37-39.

52 Dziekan Wydziału Filozoficzno-Historycznego UŁ doc. dr Waldemar Michowicz, 27 XI 1980, AUŁ, WF-H, 765, k. 12; Uchwała młodych pracowników nauki Instytutu Historii UŁ, 25 XI 1980, ibidem, 765, k. 6-10.
} 
Głos zabrali także studenci. Inspiratorem ich „wolnego zebrania” w dniu 17 grudnia 1980 r. była komórka Niezależnego Zrzeszenia Studentów (dalej: NZS) ${ }^{53}$. Poruszone przez nich kwestie ujęto w kilku grupach żądań kierowanych pod adresem władz uczelnianych. Pierwszy zestaw postulatów odnosił się do programu studiów i obejmował m.in.: żądanie wydłużenia nauki do pięciu lat, likwidacji przedmiotu marksistowska filozofia i teoria rozwoju społecznego, swobodę wyboru dwóch lektoratów, wprowadzenie dwutygodniowego okresu bez zajęć przed sesją egzaminacyjna. W bloku wniosków ekonomicznych i socjalno-bytowych znalazły się m.in.: zaliczenie czasu studiów do okresu pracy w kontekście wyliczania emerytur, rent i świadczeń socjalnych oraz zapewnienie pracy po skończonych studiach. Do tego dochodził zestaw żądań dotyczących szkolnictwa wyższego: autonomia uczelni, wyłączenie spod cenzury publikacji naukowych, udostępnienie tzw. prohibitów w bibliotekach naukowych. Natomiast w grupie tzw. innych znalazły się postulaty: rejestracji NZS, udziału przedstawicieli studentów w pracach nad aktami prawnym dotyczącym szkół wyższych, prawa powrotu na uczelnie pracowników oraz studentów usuniętych w przeszłości z powodów politycznych ${ }^{54}$.

Znakiem czasu było to, że dyrekcja odnosząc się do tych wniosków, w zasadzie je zaakceptowała. Wykazana elastyczność nie mogła jednak już nic zmienić. Od poczattku stycznia 1981 r. na uniwersytecie dojrzewała sytuacja strajkowa i nie można jej było wyhamować decyzjami z poziomu instytutowego.

Strajk na UŁ rozpoczą się 21 stycznia i $z$ czasem ogarnął też inne łódzkie uczelnie. Dodać można, że razem $z$ historykami strajkowali archeologowie, etnografowie i filozofowie. Komitetem Strajkowym w IH kierował Karol Kozłowski (IV rok historii). Codzienność strajkowa nie odbiegała od tego, co działo się w innych budynkach. Do oryginalnych przedsięwzięć zaliczyć można wydawanie pisemka strajkowego pt. „Nowsze Drogi” ${ }^{55}$.

${ }^{53} \mathrm{O}$ NZS na historii w stadium organizacji wspomniała prodziekan doc. dr hab. Alina Barszczewska-Krupa w swoim piśmie do rektora UŁ. Por. Pan Rektor Uniwersytetu Łódzkiego doc. dr habil. Tadeusz Krzemiński, 12 XI 1980, AUŁ, WF-H, 761, k. 81.

${ }^{54}$ Postulaty studentów Instytutu Historii Uniwersytetu Łódzkiego przyjęte na wolnym zebraniu NZS, 17 XII 1980, AUŁ, WF-H, 765, k. 19-23.

${ }^{55}$ K. Banaś, M. Gawryszczak, K. Lesiakowski, Strajk studencki w Łodzi styczeń-luty 1981 r. Okruchy pamięci, zapisy źródłowe, ikonografia, Łódź-Warszawa 2016 , s. 75. 
Strajk kosztował studentów wiele wysiłku. Stąd w kolejnych miesiącach zaznaczyło się obniżenie ich aktywności i dążenie przede wszystkim do nadrabiania zaległości edukacyjnych. Środowisko historyczne żyło jednak wtedy też wyborami nowych władz uczelnianych i instytutowych ${ }^{56}$, możliwościa prowadzenia niezależnej działalności w ramach NZS i Związku Młodzieży Demokratycznej, przygotowywanym projektem ustawy o szkolnictwie wyższym. Sytuacja znowu zaostrzyła się pod koniec $1981 \mathrm{r}$. w związku z konfliktem na Wyższej Szkole Inżynierskiej w Radomiu. Niezależne Zrzeszenie Studentów UŁ zdecydowało o przyłączeniu się do ogólnopolskiego strajku okupacyjnego $z$ dniem 24 listopada. Na czele powstałego wtedy komitetu strajkowego stanał Piotr Wojtczak (jego zastępca był Piotr Siczek) ${ }^{57}$. Jak się okazało, strajk nie był już tak duży i dynamiczny, jak ten $z$ lutego. Niewatpliwie przyczyniło się do tego zawieszenie 24 listopada przez rektora UŁ prof. Jerzego Wróblewskiego zajęć dydaktycznych.

Wprowadzenie stanu wojennego 13 grudnia 1981 r. wstrząsnęło życiem studentów i pracowników IH (zwłaszcza doc. K. Śreniowskiej). W następstwie akcji internowań pozbawiony został wolności student historii i członek NZS Grzegorz Haładaj. Trafił on do ośrodka w Łowiczu, gdzie przebywał do lipca 1982 r. Po zwolnieniu pozostawał w zainteresowaniu SB do $1985 \mathrm{r}$. w ramach tzw. kwestionariusza ewidencyjnego „Piegus"58. W maju 1982 r. internowano też studenta historii i socjologii Jacka Matysiaka (najpierw $\mathrm{w}$ Łowiczu, a następnie w Kwidzynie) ${ }^{59}$. W tym miejscu można też

56 Nowe władze IH wybrane przez Radę Instytutu podjęły działalność 1 IX 1981 r. Ich skład był następujacy: prof. dr hab. Władysław Bortnowski - dyrektor, doc. dr hab. Krystyna Śreniowska - zastępca dyrektora do spraw dydaktycznych, doc. dr Zbigniew Stankiewicz - zastępca dyrektora do spraw naukowych, dr Jerzy Grobis - zastępca dyrektora do spraw studiów zaocznych. Por. Sprawozdanie $z$ działalności dyrekcji Instytutu Historii UŁ za lata 1981/82 i 1982/83, 29 VI 1983, AUŁ, WF-H, 761, k. 2.

57 Obywatel Dziekan Wydziału Filozoficzno-Historycznego UŁ, 24 XI 1981, AUŁ, WF-H, 765, k. 87.

58 https://ipn.gov.pl/download/.../BIOGRAMYODZNACZONYCHWDNIU 17112017.pdf (dostęp: 28 XI 2018).

59 Ogółem na Wydziale internowano pięciu studentów, z których dwóch po zwolnieniu wyemigrowało. Pozostali wznowili studia i je ukończyli. Por. Przebieg działalności dydaktycznej na Wydziale Filozoficzno-Historycznym UŁ w latach akademickich 1981/82, 1982/83 i 1983/84, 27 VI 1984, AUŁ, WF-H, 761, k. 101; H. Marczak, Wykaz osób internowanych $w$ Ośrodku Odosobnienia $w$ Łowiczu oraz osób $z$ regionu łódzkiego internowanych $w$ innych ośrodkach odosobnie- 
wspomnieć o Andrzeju Tomaszewiczu, absolwencie historii z lat sześćdziesiątych, w tym momencie działaczu „Solidarności” w Sieradzu. Gdy trafił do ośrodka dla internowanych, odwiedzał go tam i usiłował wspomagać ówczesny dr Wiesław Puś - pracownik IH i członek Komitetu Uczelnianego PZPR.

Z ważniejszych wydarzeń będących reakcją na stan wojenny, o której należy wspomnieć, było składanie przez niektórych pracowników legitymacji partyjnych. Spośród historyków na ten krok zdecydowało się siedmiu nauczycieli akademickich $z$ grupy adiunktów i asystentów ${ }^{60}$. Niektórzy szli dalej i włączali się w działalność podziemną. W wydawanie i kolportaż "Biuletynu "Solidarność U UŁ" byli zaangażowani dr Andrzej Harasimowicz, mgr/dr Hanka Żerek, dr Henryk Michalak, dr Piotr Krupczyński i Janusz Frenkel ${ }^{61}$. Tymczasem bezpieka dla swoich potrzeb uruchomiła w listopadzie 1983 r. nowe źródło informacji rekrutujące się spośród kadry, w tym wypadku był to tzw. kontakt operacyjny ${ }^{62}$. Pozostając przy tym wątku, należy jeszcze odnotować, że w 1986 r. w IH zaczą pracować tw „Jazon”, czyli prof. Andrzej Feliks Grabski, powiazany Z bezpieka już od 1969 r. ${ }^{63} \mathrm{Z}$ dostępnych materiałów wynika, że jego obserwacje $z$ tego czasu dotyczyły jednak poziomu uniwersyteckiego, rektoratu, a nie sytuacji w instytucie.

Jeśli chodzi o sytuację studentów po stanie wojennym, to trzeba zauważyć, że w marcu 1982 r. reaktywowano zawieszone koło naukowe historyków, którego kuratorem został doc. dr Ryszard $\operatorname{Rosin}^{64}$. Należy też zwrócić uwagę na podjętą wtedy działalność

nia na terenie kraju, [w:] Internowani z regionu łódzkiego, red. M. Papis, ŁódźŁowicz 2002, s. 159, 169.

${ }^{60}$ Ogółem $z$ Wydziału Filozoficzno-Historycznego oddało legitymacje 13 pracowników, w tym jeden samodzielny. Por. Imienny wykaz samodzielnych pracowników nauki i nauczycieli akademickich Uniwersytetu Łódzkiego, którzy w okresie 1982-1984, wystapili z PZPR, 11 IV 1984, APŁ, KU PZPR UŁ, 62, k. 148-150.

${ }^{61}$ Analiza nr 4/88, 10 II 19888, AIPN Łd, Ld 0050/76, t. III, k. 25; L. O1ejnik, Prasa podziemna stanu wojennego w Łodzi (1981-1983). Wybrane problemy, „Rocznik Łódzki” 2016, t. LXV, s. 67.

${ }^{62}$ Kartoteka zniszczeniowa, AIPN Łd, Ld 0081/10, karty bez paginacji; Dziennik rejestracyjny [WUSW w Łodzi], nr 48077, ibidem, Ld 0255/4, karty bez paginacji.

${ }^{63}$ Szerzej por. S.M. Nowinowski, Andrzeja Feliksa Grabskiego żywoty równoległe, „Aparat Represji w Polsce Ludowej 1944-1989” 2007, nr 1, s. 234-269.

${ }^{64}$ Pan Prodziekan Wydziału Filozoficzno-Historycznego doc. dr hab. Waldemar Ceran, 3 III 1982, AUŁ, WF-H, 739, k. 2; Powołanie doc. dr. Ryszarda Rosina na opiekuna Studenckiego Koła Naukowego Historyków, 26 IV 1982, ibidem, k. 8. Por. też P. Budzyńs ki, op. cit., k. 46. 
na niwie samorządowej. Przyjęta w 1982 r. ustawa o szkolnictwie wyższym dawała młodzieży akademickiej taką możliwość. W tej sytuacji $z$ odpowiednią inicjatywą wystąpili także studenci historii. W dniu 4 maja 1983 r. powstała Grupa Założycielska Samorządu Studenckiego IH, którą tworzyli Piotr Jaworski, Robert Krakowiak, Maciej Łokaj, Janusz Sapiński i Jacek Walicki. Grupa zamierzała skoncentrować się na działalności socjalno-bytowej, dydaktycznej i kulturalno-oświatowej ${ }^{65}$. Wszystko wskazuje na to, że samorząd przekroczył jednak te granice. Wiosna 1984 r. samorządowcy wystapili chociażby $z$ inicjatywa zawieszenia krzyża w swoim lokalu, czemu zapobiegła zdecydowana postawa władz instytutu ${ }^{66}$. Pewnie $z$ tego kręgu wyszła też inicjatywa rozłożenia w salach przed zajęciami 16 października 1985 r. „Odezwy”, o treści nawołujaccej do bojkotu zbliżających się wyborów do Sejmu, na znak protestu przeciwko zmienionej $\mathrm{w}$ lipcu tego roku ustawie o szkolnictwie wyższym ${ }^{67}$.

Nowa ustawa w lipca 1985 r. faktycznie znosiła działalność samorządowa. O swego rodzaju marazmie, który w związku $z$ tym zarysował się wśród studentów historii, donosił SB w grudniu 1986 r. jej informator - student IV roku historii68. Zanikła też wtedy działalność zawiązanego w listopadzie 1984 r. Dyskusyjnego Klubu Filmowego, jak i klubu turystycznego „Pod górę"69. Z reaktywowaniem samorządu należało czekać do końca lat osiemdziesiątych XX stulecia. W IH został on wybrany 12 i 18 maja $1988 \mathrm{r} .^{70}$ Jego kierownictwo stanowili: Jacek Żabicki (przewodniczacy) i Przemysław Jabłoński (wiceprzewodniczący). W składzie kierownictwa samorządu zachodziły jednak duże zmiany personalne. Po niecałym roku, 8 marca 1989 r. wybrano nowy skład. W tym momencie na czele Rady Samorządu Studenckiego w IH stały następujące

${ }^{65}$ Pan Dziekan Wydziału Filozoficzno-Historycznego, 12 V 1983, AUŁ, WF-H, 707, k. 3.

${ }^{66}$ Informacja nr 143/84, 6 IV 1984, APŁ, KŁ PZPR, 1435, k. 216. Dziękuję prof. L. Olejnikowi za udostępnienie wypisu $z$ tego dokumentu.

67 Meldunek operacyjny, 16 X 1985, AIPN Łd, Pf 13/440, t. V, k. 68. Dziękuję prof. L. Olejnikowi za udostępnienie wypisu $z$ tego dokumentu.

${ }^{68}$ Notatka sporzadzona na podstawie rozmowy z k[andydatem] [na] t[ajnego] w[spółpracownika] RK, 8 XII 1986, AIPN Łd, Ld 0040/1345, k. 13.

69 Wyciag $z$ informacji od tw „Hrabia”, 19 III 1985, AIPN Łd, Ld 047/551, k. 76.

${ }^{70}$ Kilka dni wcześniej - 10 V 1988 r. - przed IH odbył się mały wiec poparcia dla rejestracji NZS. Por. J. Mikosik, Kierunek niezależność, [w:] W trybach systemu. Z dziejów łódzkiej opozycji studenckiej w latach 1968-1989, red. W. Maciejewski, A. Hohendorff, J. Mikosik, Warszawa 2016, s. 264. 
osoby: Paweł Perzyna (przewodniczacy), Marzena Jakimiak (wiceprzewodniczacca), Maciej Chocholski (sekretarz) ${ }^{71}$.

O odrodzeniu się samorządu świadczy też lista postulatów, datowana na 19 maja 1988 r. Koncentrowały się one na sprawach dydaktycznych i socjalno-bytowych. $Z$ tej pierwszej grupy najistotniejsze były: stworzenie możliwości wyboru prowadzącego ćwiczenia, zniesienie limitów przy zapisywaniu się na proseminaria i seminaria magisterskie, likwidacja protokołowania ćwiczeñ $^{72}$, zniesienie praktyk robotniczych dla osób przyjętych na I rok. W grupie postulatów socjalno-bytowych na uwage zasługuja m.in.: zwiększenie limitu wypożyczanych książek w bibliotece IH i ograniczenie zjawiska przetrzymywania książek przez pracowników, udostępnienie kserografu dla potrzeb studentów, przywrócenie działalności klubu w sali nr 48, „bo nie ma gdzie spędzać czasu po i między zajęciami", podniesienie podstawy naliczania stypendiów $^{73}$. Samorzą studencki w IH podją też konkretne działania. Zorganizowano własne obchody 70 rocznicy odzyskania niepodległości, zawieszono tablicę „upamiętniającą ofiary UB przetrzymywane w tym budynku" (wkrótce została zdjęta na polecenie wicedyrektora IH, prof. Józefa Śmiałowskiego), urządzono akcję „Kresy”, która polegała na zbiórce książek dla ludności polskiej w Zwiazku Sowieckim. O sprawności organizacyjnej samorządu studentów na historii świadczyło to, że rozpoczęli oni także przyjmowanie składek od swoich członków i sympatyków z zamiarem przeznaczenia zebranych środków na finasowanie nowych przedsięwzięć ${ }^{74}$.

Z tego wynika, że w przełomowy rok 1989 społeczność IH wchodziła w stanie sporego pobudzenia. Studenci zamierzali przyłaczyć się do walki o ponowną rejestrację NZS, zmiany w programie studiów, ze szczególnym uwzględnieniem likwidacji obowiązkowego szkolenia wojskowego. Natomiast pracownicy, a przynajmniej ich część, szukała nowych płaszczyzn działalności. Warto tu wspomnieć choćby dr. H. Michalaka, który w końcu dekady zwiąał się ze środowiskiem dążącym do odnowienia Polskiej Partii Socjalistycznej. Był delegatem na Kongres tej partii w kwietniu 1989 r.,

71 J. Mikosik, op. cit., s. 266.

72 Obowiązek ten został narzucony po wznowieniu zajęć w styczniu 1982 r.

73 Postulaty Samorzadu Studenckiego Instytutu Historii Uniwersytetu Łódzkiego, 19 V 1988, AUŁ, WF-H, 768, k. 1-2.

${ }^{74}$ J. Mikosik, op. cit., s. 281. 
a w jego trakcie został wybrany do Rady Naczelnej. Poza tym startując $z$ listy Komitetu Obywatelskiego „Solidarność”, został posłem do Sejmu kontraktowego ${ }^{75}$.

\section{Podsumowanie}

Z podanych informacji wynika, że „wielka historia” nie ominęła łódzkiego IH. Tak jak całe dzieje PRL, również historia IH nie miała jednego obrazu. W odniesieniu do kadry należy zauważyć, że szczególnym momentem kryzysowym był Marzec 1968 r. Nie oznacza to, że lata wcześniejsze czy późniejsze były stabilne i przewidywalne. Można jednak zaryzykować tezę, że równolegle do sytuacji w kraju po 1956 r. w IH następowało powolne ograniczanie presji politycznej i zwiększanie się możliwości realizacji przez pracowników swoich projektów naukowych. Powolne odrzucanie doktrynalnych ograniczeń jeszcze lepiej widać w odniesieniu do społeczności studenckiej. O ile w okresie stalinowskim została ona poddana silnej indoktrynacji, to w kolejnych dekadach zanotować należy korzystne zmiany. W efekcie $\mathrm{w}$ latach osiemdziesiątych nastąpił wręcz całkowity zanik politycznego oddziaływania na młodzież, czego wyrazem był uwiąd prorządowej organizacji ZSP. Nie oznaczało to jednak przyjęcia przez ogół studentów postawy proopozycyjnej.

Mając na uwadze zasygnalizowane powyżej zmiany warunków, w jakich przyszło funkcjonować pracownikom i studentom IH UŁ, nie można jednoznacznie odpowiedzieć na pytanie, czy zostały wykorzystane szanse na rozwój, które się pojawiały w kolejnych dziesięcioleciach (począwszy od 1956 r.). Ta kwestia pozostaje otwarta i wymaga dalszych badań.

\section{Bibliografia}

\section{$\dot{\mathbf{Z}}_{\text {RÓDEA ARCHIWALNE }}$}

Archiwum Państwowe w Łodzi [APŁ]

Komitet Łódzki Polskiej Zjednoczonej Partii Robotniczej [KŁ PZPR] 1435.

Komitet Uczelniany Polskiej Zjednoczonej Partii Robotniczej [KU PZPR] 62, 92.

${ }^{75}$ Kongres Polskiej Partii Socjalistycznej. Delegaci, 15-16 IV 1989, AIPN BU, 0248/257/7, k. 20, 24; Lista kandydatów do Sejmu i Senatu Komitetu Obywatelskiego „Solidarność”, 4 V 1989, ibidem, k. 22; H. Michalak, W sprawie programu PPS - artykut dyskusyjny, „Robotnik” 1989, nr 4, s. [2]. 
Archiwum Uniwersytetu Łódzkiego [AUŁ]

Akta osobowe 4186, 4203.

Dział Nauczania 187.

Dział Nauki 231.

Wydział Filozoficzno-Historyczny 707, 739, 761, 765, 768.

Wydział Humanistyczny 3.

Archiwum Instytutu Pamięci Narodowej Oddział w Łodzi [AIPN Łd]

Ld 0040/1345, Ld 0050/76, t. 3, Ld 0081/1, Ld 0081/10, Ld 00324/1, Ld 0255/1, Ld 0255/4, 0255/6, Ld 02255/4, 0313/12, Ld 047/551, Pf 10/51, Pf 10/52, Pf 10/310, Pf 10/525, Pf 10/706/1, Pf 10/737, Pf 10/807, 10/836, Pf 13/440, t. V.

Archiwum Instytutu Pamięci Narodowej w Warszawie - Biuro Udostępniania [AIPN BU]

00169/79/2, 0248/257/7.

Katedra Historii Polski i Świata po 1945 r. - Uniwersytet Łódzki [KHPŚ UŁ]

Materiały nieopracowane.

\section{Ż́ódea DRUKOWANE}

Banaś K., Gawryszczak M., Lesiakowski K., Strajk studencki w Łodzi styczeńluty 1981 r. Okruchy pamięci, zapisy źródłowe, ikonografia, Łódź-Warszawa 2016.

Bakowicz S., Mój uniwersytet. Wspomnienia byłego studenta, Łódź 2008.

Marzec '68 w Łodzi, red. S.M. Nowinowski, Łódź 2010.

Materiały na konferencje Zespołu Partyjnego Komitetu Nauk Historycznych PAN $w$ Instytucie Historii UŁ, Łódź 1974.

Śreniowska K., Moje życie, red. R. Stobiecki, J. Kolbuszewska, Łódź 2018.

\section{Prasa}

Michalak H., W sprawie programu PPS - artykut dyskusyjny, „Robotnik” 1989, nr 4, s. 2.

\section{Opracowania}

Banasiak S., Ewolucja struktur organizacyjnych, rozwój kadry oraz bazy materialnej instytutu, „Acta Universitatis Lodziensis”, Folia Historica 31, 1988, s. 3-19.

Banasiak S., Z dziejów Instytutu Historii, [w:] Uniwersytet Łódzki. Informator Instytutu Historii, Łódź 1998, s. 6-18.

Eisler J., Polski rok 1968, Warszawa 2006.

Kita J., Stobiecki R., Słownik biograficzny historyków łódzkich, Łódź 2000.

Lesiakowski K., Łódź, [w:] Oblicza Marca 1968, red. K. Rokicki, S. Stępień, Warszawa 2004, s. 165-185. 
Lesiakowski K., Więzienie śledcze przy ul. Gdańskiej 13, [w:] Budownictwo wojskowe $w$ Łodzi, red. W. Jarno, P. Waingertner, Łódź 2016, s. 203-220.

Marczak H., Wykaz osób internowanych w Ośrodku Odosobnienia $w$ Łowiczu oraz osób $z$ regionu łódzkiego internowanych $w$ innych ośrodkach odosobnienia na terenie kraju, [w:] Internowani z regionu łódzkiego, red. M. Papis, Łódź-Łowicz 2002, s. 147-181.

Mikosik J., Kierunek niezależność, [w:] W trybach systemu. $Z$ dziejów łódzkiej opozycji studenckiej $w$ latach 1968-1989, red. W. Maciejewski, A. Hohendorff, J. Mikosik, Warszawa 2016, s. 248-314.

Musiał F., Podręcznik bezpieki. Teoria pracy operacyjnej Służby Bezpieczeństwa $w$ świetle wydawnictw resortowych Ministerstwa Spraw Wewnętrznych PRL (1970-1989), Kraków 2007.

Nowinowski S.M., Andrzeja Feliksa Grabskiego żywoty równoległe, „Aparat Represji w Polsce Ludowej 1944-1989" 2007, nr 1, s. 234-269.

Olejnik L., Prasa podziemna stanu wojennego w Łodzi (1981-1983). Wybrane problemy, „Rocznik Łódzki” 2016, t. LXV, s. 53-81.

Olejnik L., Żydzi łódzcy w latach 1956-1972, [w:] Społeczność żydowska w PRL przed kampania antysemicka lat 1967-1968 i po niej, red. G. Berendt, Warszawa 2009 , s. $123-136$.

Osiagnięcia naukowe $i$ dydaktyczne Instytutu Historii U£ $w$ latach 1948-1988, „Acta Universitatis Lodziensis”, Folia Historica 31, 1988, s. 3-135.

Ossowski P., Czerwona Michalina. Michalina Tatarkówna-Majkowska. Przadka - działaczka - łodzianka, Łódź 2017.

Puś W., Zarys historii Uniwersytetu Łódzkiego 1945-2015, Łódź 2015.

Stobiecki R., Historia pod nadzorem. Spory o nowy model historii $w$ Polsce (II połowa lat czterdziestych - początek lat pięćdziesiatych), Łódź 1993.

Struktury i kadra kierownicza urzędów bezpieczeństwa publicznego $w$ województwie łódzkim w latach 1945-1956, red. R. Rabiega, J. Żelazko, Łódź 2019 [w druku].

Uniwersytet Łódzki. Informator Instytutu Historii, Łódź 1998.

Wróbel J., Jerzy Kosiński a tajne służby, „Aparat Represji w Polsce Ludowej 1944-1989” 2007, nr 1, s. 197-233.

\section{OpRacowania niepublikowane}

Budzyński P., Studenckie Koło Naukowe Historyków Uniwersytetu Łódzkiego 1945-2016, Łódź 2017 [praca licencjacka przechowywana w IH UŁ].

Ciota A., Działalność ZMP na Uniwersytecie Łódzkim w latach 1948-1956, Łódź 1982 [praca magisterska przechowywana w IH UŁ].

\section{Netografia}

https://ceraneum.uni.lodz.pl/o-patronie/biogram.

https://ipn.gov.pl/download/.../BIOGRAMYODZNACZONYCHWDNIU17112017.pdf. 
KRZYSZTOF LESIAKOWSKI

\section{The University of Lodz Institute of History in the realities of the Polish Peoples Republic. Chosen questions}

$\mathrm{H}$ istorical Institute (IH) of University of Lodz was established on 24 June 1948. The first years of its activity took place during the Stalinism period. The stuff and students were subjected to propaganda and were engaged in different political actions. Researches and didactics were imposed into methodology of Marxism-Leninism. The students of IH articulated their objection towards such practices in 1956 and therefore in next years, took place many positive changes. One of them was the possibility of making trips to archives and libraries in western countries. Unfortunately, in 1968 the Institute experienced many political upheavals. The consequences of anti-Semitic campaign, which were then set off, was dismissal from work and emigrating from Poland of four employees of IH. During next years, functioning of the Institute and life of the students were subjected to strong political pressure again. Its expression were e.g. working-class practices of first year students. The situation in the Institute changed only when in 1980 Independent Self-governing Trade Union "Solidarity" was created. The students and employees started to fight for their issues. The former ones took part in nearly month-long sit-down strike (January-February 1981). After the introduction of martial law two students were interned, besides the stuff and students were forbidden to conduct any independent activities. Some of them however got engaged in underground activity. The legal activity started again only in May 1988. In this time the students government on the IH was created. The students and employees joined into the transitions which took place in 1989 . One of adjuncts became even the Member of Parliament (so-called contractual Parliament).

Keywords: University of Lodz, Institute of History, Polish historians, students in Poland. 